\title{
A Need Assessment for Faculty Development in Baccalaureate Nursing Programs in Pakistan
}

\author{
Jacqueline Maria Dias $^{1} \&$ Claudio Violato ${ }^{2}$ \\ ${ }^{1}$ Aga Khan University, Karachi, Pakistan \\ ${ }^{2}$ University of Minnesota, USA \\ Correspondence: Jacqueline Maria Dias, School of Nursing \& Midwifery, Stadium Road, Karachi, Pakistan.
}

Received: March 2, 2018

doi:10.20849/ijsn.v3i1.365

\begin{abstract}
Objective: A needs assessment was undertaken for faculty development needs of nurse educators teaching in baccalaureate nursing education programs across Pakistan.

Methodology: The survey instrument was developed by the researcher in consultation with an advisory committee. It contained 25 items that reflected the demographic profile of the participants and another 98 statements on a 5 point Likert type scale to assess faculty development. Data collection was done across twenty schools of nursing.

Results: The major findings of the study indicated a critical shortage of academically prepared nursing faculty with advanced degrees and teaching experience to perform their role effectively. Female faculty outnumbered male faculty. Five factors were identified that could both promote or obstruct faculty development and included awareness and convenience, institutional support, prevailing leadership, politics and personal factors. Additionally, four factors were extracted for challenges for undertaking faculty development; technology and curriculum, students and resources, academic leadership and professional role. Lastly, four factors were identified as areas of interests for faculty development; learning and instruction, support for scholars, support for teaching and national curriculum.

Conclusion: This is the first national needs assessment that has been undertaken for faculty development for baccalaureate nursing programs in Pakistan. Although, the data may not hold international significance it would add to the existing international data base on needs assessment for faculty development.
\end{abstract}

Keywords: faculty development, baccalaureate nursing education, needs assessment, institutional support, academic leadership, nursing curriculum

\section{Introduction}

Faculty development encompasses all those activities that an institution utilizes to assist a faculty to perform their role and responsibilities (Steinhert, 2010). According to Steinhert (2010), the goal of faculty development is to sustain the vitality of the faculty by imparting the relevant skills to perform the job, thereby improving the individual faculty's knowledge and skill in three areas; teaching, research and administration (Steinhert 2010).

Moreover, faculty development should be faculty centered and based on the needs of faculty (Danilkewich et al., 2012). The best way to gauge the needs of the faculty is through a needs assessment. Need assessments are powerful tools for clarifying and validating the needs. In addition, needs assessments help to identify existing resources, or the lack of resources (Agili, 2013).

\subsection{Background and Significance}

Faculty development activities pave the way for growth and development. Universities must therefore provide an environment for faculty to fulfill their roles and responsibilities. This is essential because Universities have excellent instructors when there is an investment in faculty development (Whitcombe, 2003). Hence, supporting the intellectual capital that each faculty member represents is one of main responsibilities of higher education.

Preparation of nursing faculty with Master's level education should be the norm for teaching in baccalaureate nursing programs (Benner, Sutphen, Leonard, \& Day, 2010). However, there is an unprecedented shortage of faculty to teach in the baccalaureate programs in Pakistan (Dias \& Kurji, 2011). Additionally, the problems 
plaguing Pakistan's educational system are both recognized and documented. They include a lack of qualified faculty and ongoing faculty development, outdated methods of teaching, lack of sufficient funds and facilities, inadequate libraries and laboratories and out dated curricula (Virk,1998), (Shaikh, 1988), (Khan, Ahmad, Qureshi, Zaman, \& Afzal 2012). Given, the current nature of academia in Pakistan and the lack of clarity around faculty development for baccalaureate nursing education, a needs assessment were envisioned at the national level to understand the needs of the faculty along with the elements that promote, obstruct faculty development and challenge faculty development. Additionally, the interests of faculty for faculty development would also be assessed. Ultimately, the data obtained would lead to the understanding how these needs could be transformed into faculty development activities.

The following five questions were addressed in the study:

1. What are the prevailing faculty development activities in the schools of nursing?

2. What elements promote faculty development?

3. What elements obstruct faculty development?

4. What are the current challenges for undertaking a faculty development activity?

5. What are the current interest areas for faculty development?

\section{Literature Review}

Faculty development embraces all those activities which assist faculty members to achieve excellence in education. According to Swanwick (2008), faculty development should be an institute wide pursuit with the intent of professionalizing the educational activities of teachers, enhancing educational infrastructure and building educational capacity for the future along with organizational change (Swanwick, 2008). In short, faculty development is the lifeline for the survival of the discipline to ensure its survival into the next century (Swanwick, 2008). Also, faculty development has been documented in the literature to bring about organizational change (Jolly, 2014). According to Watkins, Meiers, and Visser (2012) need assessment is "a systematic process to identify gaps between current and desired performance to make informed decisions" (Watkins, Meiers \&Visser, 2012). In addition, need assessment also identifies the foundation for program effectiveness and tracking future efforts (McClelland, 1992). Support of stakeholders is integral to a need assessment as it endorses stakeholder's likelihood of accepting the outcomes. Grant (2002), pointed out that learning will take place at a greater degree and subsequently practice will undergo change if a needs assessment has been conducted and a link between education and practice is established. A needs assessment based on this premise will personalize the educational effort.

Haden et al. (2010) conducted a needs assessment to define professional development needs of veterinary faculty. The findings from this study indicated that respondents needs fell into four areas; topics related to teaching, research, career planning and administration. Under topics the faculty wanted to learn more about teaching like effective questioning, giving feedback, principles of learning and motivation (Haden et al., 2010).

In another study in dentistry, Agili (2013), conducted a needs assessment survey for the initiation of a Master's program in dental public health with a view to understand the level of dental public health expertise existing in the country and to identify needs and gaps and to explore perceptions. The findings revealed the need for a structured Master's level programme through a hybrid mode of delivery (Agili, 2013).

Delver (2008), in her study surveyed veterinarians in Alberta through a needs assessment for delivery preferences, topic priorities and work characteristics for continuing education. Factor analysis resulted in the learning priorities of the study participants clustering into seven distinct areas. These results provided the basis upon which continuing veterinary events could be tailored to meet the learning needs and delivery preferences for the veterinarians of Alberta (Delver, 2008).

Scarbecz et al. (2011) surveyed faculty members from six colleges including Allied Health Sciences, Dentistry, Graduate Health Sciences, Medicine, Nursing and Pharmacy to ascertain their faculty development interests. Through the process of factor analysis faculty interests were grouped in six areas; development of educational goals and objectives, the use of innovative teaching techniques, clinical teaching, improving traditional teaching skills, addressing teaching challenges and facilitating participation. The study affirmed that faculty interests do not fall into predetermined classifications and has implications for the design and delivery of faculty development programs to enhance teaching skills (Scarbecz, Russell, Shreve, Robinson, \& Shield, 2011).

In another study Amin et al. (2009) conducted a needs assessment survey in Singapore to determine the educational needs and priorities of clinical faculty. This study found that study participants had higher 
knowledge levels in areas related to teaching and somewhat lesser knowledge in assessment and educational concepts (Amin et al., 2009). Tiwari, Sharma, and Zodpey (2012) from India report on the situational analysis of nursing education and workforce in India. This article mirrors the current state of nursing education in Pakistan. India is facing multiple challenges; including enriching the existing curriculum to make it reflective of the trends in the health care system, strengthening the nurse teacher education by providing more opportunities for nurse teachers to obtain further qualification of Masters and doctoral education and improving the infrastructure. (Tiwari, Sharma, \& Zodpey, 2012)

\section{Methodology}

Items for the questionnaire were derived from the design and theoretical underpinnings of faculty development and adult learning theory literature, discussions with experts and colleagues in the profession, and the researcher's personal experiences and observations.

The questionnaire had two parts. The first section gathered demographic information on the faculty and institutional efforts for supporting faculty in their roles and responsibilities.

The 25 items related to the relevant socio demographic data with regards to sex, academic rank, employment status, age, current salary, highest academic qualification, additional diplomas, years of experience as a nurse, years of experience as faculty, formal training to become a teacher, length of the training and conduction of training. In addition, items related to interests in faculty development, reasons for undertaking faculty development, current nature and engagement in faculty development activities was ascertained. Also payment for faculty development activities undertaken and study leave / conference leave obtained and requirements by institutions to obtain funding for faculty development were obtained.

The second part of the survey tool sought to elicit study respondents' opinions on a Likert type scale of 1 to 5 , with responses ranging from not important to highly important. There were a total of 98 items, which were grouped into 4 categories; 6 items that promoted faculty development, 19 items that obstructed faculty development, 16 items that were challenges to undertaking faculty development and 57 items which were interests in faculty development. An open ended question was included under each subscale to elicit information about additional needs, not addressed in the survey. Content validity of the instrument was established through literature review and review by a panel of 5 experts who were familiar with the context of nursing education in Pakistan.

A total of 270 questionnaires were distributed. A total of 230 faculty members responded to the survey which makes the response rate $85.15 \%$. Descriptive analysis was done for all 230 respondents to summarize the demographic profile of the study respondents. Upon completion of the data collection process, an exploratory factor analysis was used to reduce the data set into smaller sets of variables. The subscale internal consistency reliability, within items that promote and obstruct faculty development, challenges for undertaking faculty development, and interest areas for faculty development, was assessed by calculating values using Cronbach's alpha for each subscale. Data from all these areas were subjected to exploratory factor analysis to assess the construct validity of the scale as a data reduction technique. Items with eigenvalues greater than 1 loading primarily onto one factor were considered constituents of that factor. Exploratory factors analysis determined which items on the survey belonged together as well as described the variance for each factors. These factors established through factor analysis went on to become principal domain of the study. Varimax rotation was used to maximize the variance in the data explained by each factor and a Cronbach alpha coefficient was calculated as a measure of the internal consistency reliability. The level statistical was set at $\mathrm{p} \leq 0.05$ across the study.

The study received approval from the University Ethical Review Committee. To maintain the human rights, both institutional approval and individual consents were taken from the research participants.

\section{Results}

\subsection{Demographic Characteristics of the Participants}

The majority of the sample belonged to private universities $(n=156,68 \%)$ and were predominately women $(n=$ $161,70 \%)$. The distribution according to faculty rank was as follows: Lecturer $(\mathrm{n}=32,14 \%)$, Instructors $(\mathrm{n}=88$, $38 \%$ ), Senior Instructors ( $\mathrm{n}=78,34 \%)$, Assistant Professors $(\mathrm{n}=23,10 \%)$, Associate Professors $(\mathrm{n}=3,1.3 \%)$. Of all the respondents, $78 \%$ were instructors and senior instructors. The majority of the respondents $(n=211,92 \%)$ held full time positions.

Almost $50 \%$ of the respondents were in the age range between 26-35 years. All the participants had a baccalaureate degree in nursing. In addition, $41 \%(\mathrm{n}=94)$ had a Master's degree while $3.5 \%(8)$ had a doctorate. In addition $35 \%$ participants $(\mathrm{n}=80)$ had a further qualification of a one year advanced diploma which was in 
either midwifery, cardiology, community nursing, pediatrics, critical care, mental health, ward administration or teaching administration. The monthly salary for faculty ranged from Rs. 20,000 (US\$200) to over Rs. 200,000 (US $\$ 2000$ ) with the majority ( $n=60,26 \%$ ) in the range between Rs. 21,000 to Rs. 30,000 (US \$210- US\$300).

The demographic variables further explored the total years of experience in nursing and number of years of experience as a faculty in a school of nursing. The total years of experience ranged from less than one year to over twenty years. The majority of participants' work experience ranged between five to ten years $(n=63,27.4 \%)$. Study participants with less than five years work experience were fifty six (24.3\%).

Formal teaching experience ranged from less than one year to over twenty years. The majority of participants' fell in the range of $5-10$ years $(\mathrm{n}=61,26.5 \%)$ followed by the next category of respondents having two to three years of teaching experience $(\mathrm{n}=54,23.5 \%)$.

One hundred and twenty eight $(55.7 \%)$ reported that they had received some formal training to become a faculty while one hundred and two (44.3\%) had not received any training. For those who had received formal training to become a faculty, the length of the formal training ranged from a day to a year. Fifty seven (24.8\%) participants had received a year's training while thirty eight $(16.5 \%)$ had received a week's training to become a faculty. Thirty (13.0\%) study participants reported that they had received a month's training; while nine (3.9\%) reported their training to be a faculty was limited to one day. The majority of respondents reported that the training to become a faculty was conducted by their own institutions $(n=61,26.5 \%)$, while $(n=46,20 \%)$ undertook a formal one year advanced diploma to become a faculty. Another fifteen (6.5\%) received national training while eleven $(4.8 \%)$ undertook an elective in education as part of their baccalaureate or master's degree program.

The majority of the respondents $(\mathrm{n}=225,97.5 \%)$ affirmed their interest in faculty development for their role as teacher, and indicated the reasons for undertaking faculty development included improvement in performance $(\mathrm{n}=82,35.7 \%)$, increase in salary $(\mathrm{n}=59,25.7 \%)$ and increased opportunities for career growth $(\mathrm{n}=58,25.2 \%)$, while eleven (4.7\%) did not respond to this question.

At the time of the survey one hundred and seventy five (76.1\%) were involved in faculty development activities while fifty five $(23.9 \%)$ reported they were not involved in any faculty development activity. Current faculty development activities undertaken included primarily attendance at workshops $(\mathrm{n}=88,38.3 \%)$ as well as pursuing a degree; Master's in nursing $(n=30,13 \%)$ and a doctorate degree $(n=4,1.7 \%)$. In addition, the majority of respondents $(\mathrm{n}=224,97.4 \%)$ were involved in self-directed activities for their own faculty development. Reading relevant literature $(n=91,82.6 \%)$ followed by surfing the internet $(n=15,6.5 \%)$ were reported as the primary form of self-directed activities. Also mentoring as a form of faculty development was reported by a minority of participants $(\mathrm{n}=17,7.9 \%)$.

Seventy five (32.6\%) study participants rated the faculty development activities provided by their institutions as good. The majority of the respondents had undertaken faculty development activities over the last year $(\mathrm{n}=161$, $70 \%)$. These faculty development activities included: $(\mathrm{n}=94,40.9 \%)$ in the area of teaching and learning followed by $(\mathrm{n}=28,12.2 \%)$ in assessment, and $(\mathrm{n}=18,7.8 \%)$ in research methodology, followed by $(\mathrm{n}=11,4.8 \%)$ in curriculum and lastly $(\mathrm{n}=10,4.3 \%)$ in evaluation. In contrast, over the last five years $(\mathrm{n}=45,19.6 \%)$ the study participants had undertaken faculty development activities in teaching and learning, $(\mathrm{n}=12,5.2 \%)$ in assessment, $(n=5,2.2 \%)$ research methodology and $(n=8,3 \%)$ curriculum and $(n=7,3.7 \%)$ in evaluation.

Furthermore, over the last five years the majority of the respondents had not attended any faculty development activity $(\mathrm{n}=153,66.5 \%)$. Some study participants reported that they pursued higher education as part of faculty development activities; Post RN BScN studies was undertaken by thirteen study participants (8.2\%) and MScN (Masters of Science in Nursing) by six participants $(2.6 \%)$ in the last five years.

In terms of payment for faculty development activities, seventy three (31\%) paid for the activity themselves, while sixty three (27.4\%) reported their institutions had paid for their activities while six $(2.6 \%)$ reported that the cost of the faculty development activity was collectively borne by the institution and the study respondents. Fifty six (24.3\%) reported that the faculty development activities undertaken were free of cost.

For those who had undertaken faculty development activities in the last one year the amount of money spent on faculty development ranged from Rs.50 to over Rs.100,000 (US\$ 0.5 - US \$1000). The majority of study participants reported $(n=46,20 \%)$ that the amount of money spent was between Rs. 1000 - Rs. 5000 (US $\$ 10$ US $\$ 50$ ) by the individual participants.

For those who had undertaken faculty development activities in the last five years, the amount of money spent on faculty development ranged from Rs.500 to over Rs.100,000 (US\$5 - US \$1000) with the majority ( $\mathrm{n}=34$, $14.8 \%$ ) of money spent was between Rs. 1000 - Rs. 5000 (US \$10- US\$50) by the individual participants. 
Study respondents reported that their institutions spent between Rs.500 to over Rs.100,000 (US\$5 - US\$1000) on their faculty development activities in the last five years. Nineteen $(8.3 \%)$ study participants reported that the institution had borne more than Rs.100,000 (US\$1000) of the cost for faculty development activities. Fifty five (23.9\%) participants reported they filled out a service bond as payment for faculty development activities.

Requirements to obtain institutional funding included; attending an accredited university ( $\mathrm{n}=77,35 \%$ ), pursuing a degree that is work related $(\mathrm{n}=48,20 \%)$ and completing a certain time period in the institution before study participants were able to obtain funding $(n=34,14.6 \%)$. Additionally, $(n=31,13.5 \%)$ reported they had signed a service bond with their school of nursing in order to receive funding for faculty development while thirty one $(13.5 \%)$ did not respond to the question.

One hundred and twenty eight (55.7\%) study participants had received study leave or conference leave while one hundred and two (44.3\%) study participants reported they had never received study leave or conference leave for attending a faculty development activity. The range of conference leave or study leave received over the last year ranged from one day to two years. The majority of study leave received was one day $(\mathrm{n}=31,13.5 \%)$, five days $(\mathrm{n}=20,8.7 \%)$, three days $(\mathrm{n}=19,8.3 \%)$, seven days $(\mathrm{n}=13,5.7 \%)$ and two years $(\mathrm{n}=9,3.9 \%)$. The category of the conference leave was attendance for local conferences $(n=76,33 \%)$, national conferences $(n=36,15.7 \%)$ regional conferences $(n=2,0.9 \%)$ and international conferences $(n=16,7.0 \%)$.

Conference leave or study leave received over the last five years ranged from one day to two years. The majority of study participants obtained study leaves for two days $(n=21,9.1 \%)$ followed by five days $(n=16,7 \%)$ followed by three days $(n=9,3.9 \%)$. Eight $(3.5 \%)$ received study leave for two years to pursue a degree in nursing. The category of the conference or study leave received was for local conferences $(n=34,14.8 \%)$, national conferences $(\mathrm{n}=28,12.2 \%)$, regional conferences $(\mathrm{n}=2,0.9 \%)$ and international conferences $(\mathrm{n}=24$, $10.4 \%$ ). In addition, eight study respondents (3.5\%) received study leave for two years to pursue a Post RN $\mathrm{BScN}$ degree or Master's degree in Nursing.

The main benefit from attending faculty development sessions reported by the overwhelming majority of study respondents was personal growth $(\mathrm{n}=194,84.9 \%)$ followed by scholarly growth $(\mathrm{n}=17,17.4 \%)$ and lastly promotion $(\mathrm{n}=11.4,4.8 \%)$.

Table 1. Internal consistency reliability

\begin{tabular}{ll}
\hline Cronbach's Alpha & N of items \\
\hline .978 & 98 \\
\hline
\end{tabular}

The reliability of the data using Cronbach's alpha was 0.978 . Cronbach's alpha measures internal consistency among items on an instrument. The sub scale reliabilities are shown in tables 2, 3\&4. The ninety eight items were analyzed using the Principal Component Analysis with Varimax rotation with Kaiser Normalization. The final number of factors was determined using the Kaiser rule with Principal Component Analysis of factors having Eigen values $>1.00$. The factor loading resulting from factor analysis represents the strength of the relationship between an item and the underlying factor (Portney \& Watkins, 2000). Also, items that loaded at 0.40 or greater were included as an item for the given factor. Progressively limiting the number of factors produced five factors that promoted and obstructed faculty development, four factors for challenges for undertaking faculty development and five factors for interests in faculty development. This explained $61.64 \%$ variance in the factors that promoted faculty development and were obstacles for faculty development, while the challenges had a variance of $72.96 \%$ and for interest the variance was $68.52 \%$. 
Table 2. Principal component analysis with varimax rotation and kaiser normalization of factors that promote or obstruct faculty development

\begin{tabular}{|c|c|c|c|c|c|}
\hline \multicolumn{6}{|c|}{ Principal Component Analysis with Varimax with Kaiser Normalization of Factors that Promoted or } \\
\hline & Factor & & & & \\
\hline & 1. Awareness & 2. Institutional & 3. & 4. & 5. \\
\hline & & Support & Prevailing & Politics & Personal \\
\hline & Convenience & & Leadership & & Factors \\
\hline Institutional structure & & .679 & & & \\
\hline Institutional support & & .819 & & & \\
\hline Ongoing professional growth & & .831 & & & \\
\hline Resources & & .804 & & & \\
\hline Teaching excellence & & .691 & & & \\
\hline Protected time & & .687 & & & \\
\hline Prevailing political conditions & & & & .722 & \\
\hline Insufficient time & & & & .677 & \\
\hline Lack of institutional support & & & .611 & .510 & \\
\hline Stress & & & & & .697 \\
\hline Burnout & .401 & & & & .655 \\
\hline Lack of institutional commitment & & & .732 & & \\
\hline Unsupportive leadership & & & .827 & & \\
\hline Favoritism & & & .691 & & \\
\hline Departmental nomination & .436 & & .526 & & \\
\hline Lack of faculty motivation & .562 & & .446 & & \\
\hline Timing of event & .721 & & & & \\
\hline Location & .758 & & & & \\
\hline Transportation & .791 & & & & \\
\hline Awareness & .769 & & & & \\
\hline Topics & .763 & & & & \\
\hline Workload & .618 & & & & \\
\hline Resource allocation & .766 & & & & \\
\hline Family commitments & .627 & & & & \\
\hline$\%$ of Variance & 21.6 .25 & 13.953 & 12.911 & 7.065 & 6.095 \\
\hline Alpha reliability & .460 & .842 & .800 & .007 & .100 \\
\hline
\end{tabular}

Table 3. Principal component analysis with varimax rotation and kaiser normalization for challenges

\begin{tabular}{|c|c|c|c|c|}
\hline \\
\hline \multicolumn{5}{|c|}{$\begin{array}{l}\text { Principal Component Analysis with Varimax with Kaiser Normalization for Challenges } \\
\text { Factor }\end{array}$} \\
\hline & 1. Technology & & 3. & \\
\hline & $\&$ Curriculum & Students \& & Academic & Professional \\
\hline & & Resources & Leadership & Role \\
\hline Existing faculty development infrastructure & & & .836 & \\
\hline $\begin{array}{l}\text { Provision of ongoing professional growth } \\
\text { opportunities }\end{array}$ & & & .841 & \\
\hline Departmental leadership & & & .765 & \\
\hline Changing Faculty roles & & & & .471 \\
\hline Obtaining funding & & .740 & .401 & \\
\hline Availability of necessary resources & & .665 & .406 & \\
\hline Integrated curriculum & .564 & .554 & & \\
\hline Diverse student population & .486 & 678 & & \\
\hline New Technologies & .804 & & & \\
\hline Simulations & .809 & & & \\
\hline E -Learning & .782 & & & \\
\hline Maintaining a work life balance & & & & .778 \\
\hline Working in a multidisciplinary teams & .615 & & & .636 \\
\hline Timing of event & & & & .760 \\
\hline Multiple priorities & & .698 & & .459 \\
\hline Teaching underprivileged students & .472 & .609 & & \\
\hline$\%$ of Variance & 21.202 & 19.515 & 16.751 & 15.496 \\
\hline Alpha reliability & .444 & .335 & .382 & .837 \\
\hline
\end{tabular}


Table 4. Principal component analysis with varimax rotation and kaiser normalization for interest

\begin{tabular}{|c|c|c|c|c|c|}
\hline \multicolumn{6}{|c|}{ Principal Component Analysis with Varimax with Kaiser Normalization for Interest } \\
\hline & Factor & & & & \\
\hline & & 2. & 3. & 4. & 5. \\
\hline & Learning \& & Support & Faculty & Support & National \\
\hline & Instruction & for & Development & for & Curriculum \\
\hline \multicolumn{5}{|l|}{ Orientation to National Curriculum } & .687 \\
\hline \multicolumn{6}{|l|}{ Guidelines } \\
\hline Course Design & & & & & .776 \\
\hline Curriculum Development & & & & & .762 \\
\hline Classroom Management & & & & & .587 \\
\hline $\begin{array}{l}\text { Designing \& Teaching Web based } \\
\text { or Distance Learning }\end{array}$ & & .598 & & & \\
\hline Teaching Strategies for Adult & .655 & & & & \\
\hline \multicolumn{6}{|l|}{ Learners } \\
\hline Developing Student Critical Skills & .654 & & & & \\
\hline Clinical Teaching & .625 & & & & \\
\hline Large Classroom Sessions & .539 & & & & \\
\hline Small Group Teaching & .680 & & & & \\
\hline Giving Feedback & .705 & & & & \\
\hline Concept Mapping & .714 & & & & \\
\hline Writing Instructional Objectives & .717 & & & & \\
\hline Teaching Using Simulation & .713 & & & & \\
\hline Dealing with Difficult Students & .703 & & & & \\
\hline Constructing Quality Test & .645 & & & & \\
\hline \multicolumn{6}{|l|}{ Questions } \\
\hline Evaluating Test Results & .611 & & & & \\
\hline Peer Coaching /Peer Mentoring & .642 & & & & \\
\hline Video Tape \& Feedback & .679 & & & & \\
\hline Working in Teams & .751 & & & & \\
\hline Lecturing & .706 & & & & \\
\hline Giving Presentations & .751 & & & & \\
\hline Use of Role Plays & .733 & & & & \\
\hline $\begin{array}{l}\text { Level of interest for How to use } \\
\text { standardized Patients }\end{array}$ & .726 & & & & \\
\hline Utilizing Search Engines & .726 & & & & \\
\hline Evaluating Learners on Clinical & .742 & & & & \\
\hline Integrating Evidence Based & .633 & & & & \\
\hline \multicolumn{6}{|l|}{ Teaching Practice } \\
\hline Mentoring Skills & .738 & & & & \\
\hline Preceptorship Skills & .715 & & & & \\
\hline $\begin{array}{l}\text { How to stimulate self-directed } \\
\text { learning in students }\end{array}$ & .667 & & & & \\
\hline How to use Computers and & .646 & & & & \\
\hline \multicolumn{6}{|l|}{ Information Technology } \\
\hline Forming Research Methodology & & .792 & & & \\
\hline \multicolumn{6}{|l|}{ Support Units } \\
\hline \multicolumn{2}{|l|}{$\begin{array}{l}\text { Faculty Exchange Programs within } \\
\text { the country }\end{array}$} & .759 & & & \\
\hline \multicolumn{2}{|l|}{$\begin{array}{l}\text { Faculty Exchange Programs } \\
\text { outside the country }\end{array}$} & .821 & & & \\
\hline \multicolumn{2}{|l|}{ Obtain Grants for Teaching } & .713 & & & \\
\hline \multicolumn{6}{|l|}{ Improvements } \\
\hline Obtain Grants for Student Research & & .724 & & & \\
\hline $\begin{array}{l}\text { Level of interest for Obtain Grants } \\
\text { for Technology }\end{array}$ & & .573 & & .549 & \\
\hline
\end{tabular}




\begin{tabular}{|c|c|c|c|c|c|}
\hline \multicolumn{6}{|c|}{ Principal Component Analysis with Varimax with Kaiser Normalization for Interest } \\
\hline & $\begin{array}{l}\text { Factor } \\
1 . \\
\text { Learning \& } \\
\text { Instruction }\end{array}$ & $\begin{array}{l}2 . \\
\text { Support } \\
\text { for } \\
\text { Scholars }\end{array}$ & $\begin{array}{l}3 . \\
\text { Faculty } \\
\text { Development }\end{array}$ & $\begin{array}{l}4 . \\
\text { Support } \\
\text { for } \\
\text { Teaching }\end{array}$ & $\begin{array}{l}5 . \\
\text { National } \\
\text { Curriculum }\end{array}$ \\
\hline $\begin{array}{l}\text { Circulation of Newsletters / Articles } \\
\text { that are pertinent to teaching } \\
\text { improvement }\end{array}$ & & & & .582 & \\
\hline Employee support Programs & & & & .624 & \\
\hline Formation of online support groups & & .465 & & .645 & \\
\hline $\begin{array}{l}\text { University Policies for Faculty } \\
\text { Development }\end{array}$ & & & .442 & .601 & \\
\hline Academic Advising \& Counseling & .441 & & & .570 & \\
\hline $\begin{array}{l}\text { Developing Productive } \\
\text { Assignments }\end{array}$ & .451 & & & .502 & \\
\hline Use of Maintaining Data Bases & .412 & & .413 & .404 & \\
\hline $\begin{array}{l}\text { Data Analyses Using Statistical } \\
\text { Methods }\end{array}$ & & .541 & & & \\
\hline Motivating Students & .543 & & .498 & & \\
\hline Use of Effective Questioning & .547 & & .498 & & \\
\hline Developing Case Studies & .418 & & .611 & & \\
\hline $\begin{array}{l}\text { Effective Utilization of Student } \\
\text { Evaluation }\end{array}$ & .440 & & .560 & & \\
\hline Student Support Systems & .411 & & .622 & & \\
\hline Detection of Plagiarism & & & .615 & & \\
\hline Use of Reference system & .436 & & .536 & & \\
\hline $\begin{array}{l}\text { Developing your own teaching } \\
\text { portfolio }\end{array}$ & .447 & & .661 & & \\
\hline $\begin{array}{l}\text { Writing Scholarly Manuscripts \& } \\
\text { Conference Proposals }\end{array}$ & & 648 & .443 & & \\
\hline Designing \& Conducting & & 699 & .414 & & \\
\hline Classroom Based Research & & & & & \\
\hline Self-assessment of teaching Skills & & & .730 & & \\
\hline Preventing Professional Burnout & & & .561 & & \\
\hline$\%$ of Variance & 27.964 & 13.935 & 11.985 & 8.967 & 5.690 \\
\hline Alpha reliability & .783 & .614 & .493 & .246 & .701 \\
\hline
\end{tabular}

\subsection{Factor Analysis}

Five factors were identified that could both promote or obstruct faculty development. These five factors included awareness and convenience, institutional support, prevailing leadership, politics and personal factors. Additionally, four factors were extracted for challenges for undertaking faculty development; technology and curriculum, students and resources, academic leadership and professional role. Lastly, four factors were identified as areas of interests for faculty development; learning and instruction, support for scholars, support for teaching and national curriculum.

\section{Discussion}

The present study affirmed that nursing is still a female dominated profession in Pakistan (Harding 2009; Zamanzadeh, Valizadeh, Negaranden, Monardy \& Azadi, 2013). The major findings outlined that there is a critical shortage of well-trained faculty with advanced nursing degrees and teaching experience to perform the role of faculty. Also, female faculty outnumbered male faculty. Giving presentations, working in teams, evaluating learners on clinicals, use of role plays and mentoring skills were listed as areas where faculty development was most required. Nursing faculty has not received any formal training in instructional skills. Clark et al. (2004), have pointed out that faculty require a range of skills to teach and assess learners, provide feedback and develop and evaluate curricula. In addition, one of the key findings emanating from this study is that mentorship needs to be formalized, as currently it is underutilized within nursing. Given that Pakistan has a 
relatively younger faculty, mentoring should be the driving force to harness the potential of the novice faculty. This would be in line with the literature, as mentorship has been acknowledged as the way forward for career growth, job satisfaction, and increased productivity of novice nurse educators (Dunham-Taylor, Lynn, Moore, McDaniel \&Walker,2008; NLN 2006; Bland, Seaquist, Pacala, Center \& Finstand,2002; Pololi, Knight, Dennis \& Frankel 2002; Tsen et.al., 2012; Lowenstein et al., 2007; Haines, Pharma, \& Popovich. 2014). Faculty exchange programs within the country and outside the country indicate a dire need for the faculty to communicate with other faculty and exchange ideas. These exchange programs build partnerships and linkages within the country and outside the country. Upvall, Leffers, and Mitchelle (2014) have described the importance of fostering partnerships through national and international collaboration and linkages (Upvall, Leffers, \& Mitchell, 2014). Faculty linkages build the capacity of nurses which has long lasting effects on teaching, research service, professional and organizational management (Rosenkoetter \& Nardi, 2007). Therefore, if the concept of faculty exchanges is embraced at a national level it would open up a host of opportunities for nursing faculty to network and learn from each other. Undertaking research was another area which needed attention. Nursing faculty in Pakistan understand the need for research to improve their teaching practices but require support to carry out research. This is in line with the literature that grants given to support courses, purchase of educational software, and support to attend conferences have had long reaching effects in terms of teaching improvement (Lee, 2010).

Also, the study highlighted faculty participation in faculty development activities. Steinhert et al. (2010) has pointed out in a systematic review of faculty development programs there is a high level of satisfaction among faculty who attended programs to improve teaching (Steinhert et al., 2010). Furthermore, Scarbecz et al. (2011) noted that faculty development activities that encompass teaching and learning strategies have demonstrated an improvement in teaching behavior and practice (Scarbecz et al., 2011). Furthermore, students face numerous challenges which include; health, finances and academics. Effective student support systems facilitate faculty members to help students' cope with the multiple stressors they face during university (Dent \& Rennie, 2009).

Furthermore, faculty need to be taken care of and their needs met. Two ways to meet faculty needs are: through the formation of support groups and employee support programs. Today, in the digital world, online support groups are rapidly gaining prominence. The literature offers teaching circles and faculty learning communities similar to communities of practice where faculty come together for support and address issues that are pertinent to teaching (Lee, 2010; Lave \& Wagner 1991; Steinhert, 2010). The majority of faculties are young and have not received formal teacher training or educational preparation in curriculum development. Keating (2015) asserts in such situations it becomes the responsibility of the individual schools of nursing to orientate new faculty to curriculum development and learner centered education (Keating 2015). Dias et al. (2010) pointed out that in Pakistan the absence of prepared faculty were key constraints in the operationalization of the national curriculum (Dias et al., 2010). Additionally, as many faculties have not received any formal education in teaching and learning they need to learn the basics of curriculum development, course design and classroom management.

\section{Recommendations}

The following recommendations arise from the study including the training of nurse faculty both for teaching and clinical. Also, there should be institutional support for faculty development and an investment in the infrastructure for teaching aids, up gradation of skills laboratories and science laboratories. Innovative teaching learning methodology, like e-learning and blended learning should be employed. Furthermore, guidance and supervision should be provided by mentors to the young faculty. Regulatory bodies should ensure ongoing faculty development programs through communities of practice.

\subsection{Strengths}

To the author's knowledge this is the first national needs assessment that has been undertaken for faculty development for baccalaureate nursing programs in Pakistan The survey provides information that is contextually relevant to Pakistan. The broad based sampling across the country, along with the high response rate and the sound psychometric properties of the questionnaire, are all salient features of this study.

\subsection{Limitations}

There are several limitations of the study. This study is an attempt to provide information about what is generally unknown in the area of faculty development needs of the nursing faculty. The questionnaires were distributed by the Head of the Schools of Nursing. There is the possibility that some of the questionnaires were not returned if the participants had divulged information which would have a harmful reputation of the school. An additional limitation, could be the biasedness of the participants and their willingness to share or disclose information. Lastly, there is the possibility of an acquiescence bias. 


\subsection{Conclusion}

This study will contribute to the international data base for need assessment on faculty development in nursing within Pakistan. The findings from the study can provide baseline data for faculty development initiatives across Pakistan.

\section{References}

Agili, Al. (2013). A needs assessment for a Master's program in dental public health in Jeddah Saudi Arabia. Advances in Medical Education, 4, 55-68. https://doi.org/10.2147/AMEP.S41173

Amin, Z., Eng, K.H., Seng, C.Y., Hoon, T.C., Sun, G.P., Samarasekera, D.D., ... Rhoon, K.D. (2009). A Multi-Institutional Survey on Faculty Development Needs, Priorities and Preferences in Medical Education in an Asian Medical School. Medical Education Online, 14, 16. https://doi.org/10.3885/meo.2009.Res00317

Benner, P., Sutphen, M., Leonard, V., \& Day, L. (2010). Educating Nurses: A Call for Radical Transformation. Jossey Bass: San Francisco, US.

Bland, C.J., Seaquist, E., Pacala, J.T., Centre, B., \& Finstad, D. (2002). One school's strategy to assess and improve the vitality of its faculty. Academic Medicine, 77(5), 367-376. https://doi.org/10.1097/00001888-200205000-00004

Centra, J.A. (1978). Types of faculty development programs. Journal of Higher Education, 49(2), 151-162. https://doi.org/10.1080/00221546.1978.11776610

Clark, J.M., Houstan, T.K., Kolonder. K., Branch, W.T., Levine, R.Z.B., \& Kern, D.E. (2004). Teaching the Teachers: National Survey of Faculty Development in Departments of Medicine of U.S Teaching Hospitals. J Gen intern Med., 19, 205-214. https://doi.org/10.1111/j.1525-1497.2004.30334

Danilkewich, A.D., Kuzmicz, J., Greenberg, G., Gruszezynski, A., McKague, M., Bonnycastle, D., ... Ramsden, V.R. (2012). Implementing an evidence-informed faculty development program. Can Fam Physician, 58(6), 337-343.

Delver, H.A. (2008). Continuing Veterinary Medical Education Needs and Delivery preferences of Alberta Veterinarian, Journal of Veterinary Medical Education, 35(1), 129-137. https://doi.org/10.3138/jvme.35.1.129

Dent, J.A., \& Rennie, S. (2009). Student Support System. In Dent, J.A. \& Harden, R.M. (Eds.), A Practical Guide for Medical Teachers (4th ed.). Edinburgh: Churchill, Livingstone.

Dias, J.M., \& Kurji, Z. (2011). Evaluation of teaching and learning course in the nursing baccalaureate curriculum in one University teaching Hospital in Karachi, Pakistan, Procedia-Social and Behavioral Sciences, (15), 2963-2966. https://doi.org/10.1016/j.sbspro.2011.04.223

Dias, J.M., Ajani, K., \& Mithani, Y.M. (2010). Conceptualization and operationalization of a baccalaureate nursing curriculum in Pakistan: challenges, hurdles and lessons learnt. Procedia-Social and Behavioral Sciences, 2(2), 2335-2337. https://doi.org/10.1016/j.sbspro.2010.03.332

Dunham-Taylor, J., Lynn, C., Moore, P., McDaniel, S., \& Walker, J. (2008). What goes around comes around: Improving faculty retention through more effective mentoring. Journal of Professional Nursing, 24, 337-346. https://doi.org/10.1016/j.profnurs.2007.10.013

Grant, J. (2002). Learning needs assessment: assessing the need. British Medical Journal, 19, 156-159. https://doi.org/10.1136/bmj.324.7330.156

Haden, M.H., Chaddock, M., Hoffsis, G.F., Llyod, J.W., Reed, W.M., Ranney, R.R., \& Weinstein, G.J. (2010). Preparing faculty for the future: AAVMC members perception of professional development needs. $J$ Vet Med Edu., 37(3), 220-232. https://doi.org/10.3138/jvme.37.3.220

Haines, S.L., Pharma, D., \& Popovich, N.G. (2014). Faculty Development: engaging external senior faculty members as faculty mentors. American Journal of Pharmaceutical Education, 78(5), 101. https://doi.org/10.5688/ajpe785101

Harding, T. (2009). Swimming against the male stream: men choosing nursing as a career. Nursing Praxis in New Zealand, 25(3), 1-22.

Jolly, B. (2014). Faculty Development for Curriculum Change: towards a competency-based teaching and assessment. In Y. Steinhert (Ed.), Faculty development in the Health Professions: A focus on research, practice, innovation and change in professional education. New York: Springer Sc.

Keating, S.B. (2015). Curriculum Development and Evaluation in Nursing (3rd ed.). USA: Springer Publishing Company. 
Khan, N., Ahmed, K.F., Qureshi, M.I., Zaman, K., \& Afzal, S.M. (2012). Effectiveness of Higher Education Faculty Development Projects with Particular Reference to Research.

Lave, J., \& Wenger, E (1991). Situated learning: legitimate peripheral participation. Cambridge MA: Cambridge University Press. https://doi.org/10.1017/CBO9780511815355

Lee, V.S. (2010). Program types and Prototypes. In Gillespie, K.J. \& Robertson, D.L. (Eds.), Guide to Faculty Development. San Franciso: Jossey Bass.

Lowstein, S.R., Fernandez, G., \& Crane, L.A. (2007). Medical school faculty discontent: prevalence and predictors of intent to leave academic careers. $B M C, 7,37$.

McClelland, S.B. (1992). A systems approach to needs assessment. Train Dev, 46(8), 51-53.

National League for Nursing. (2006). Position statement: Mentoring of nurse faculty. Nursing Education Perspectives, 27, 110-113.

Polili, L.H., Knight, S.M., Dennis, K., \& Frankel, K. (2002). Helping medical school faculty realize their dreams, an innovative, collaborative mentoring program. Academic Medicine, 77, 377-384. https://doi.org/10.1097/00001888-200205000-00005

Rosenkoetter, M.M., \& Nardi, D.A. (2007). American academy of nursing expert panel on global nursing and health: White paper on global nursing and health. Journal of Transcultural Nursing, 18(4), 305-315. https://doi.org/10.1177/1043659607305188

Scarbecz, M., Russell, C.K., Shreve, R.G., Robinson, M.M., \& Shield C.R. (2011). Faculty Development to Improve Teaching at a Health Sciences Centre: A Needs Assessment. Journal of Dental Education, 75(2), 145-159.

Shaikh, N. (1998). Higher Education in Pakistan: the public sector. In Talati,J.T., Vellani, C.W., Herberg, P., Sutton, R.Al.L., Qureshi, A.F., Pradhan. S. \& Bacchus, K. (Eds.), Higher education a pathway to development (pp. 33-44). Karachi: Aga Khan University \& Oxford University Press.

Steinhert, Y. (2010). Faculty development: from workshops to communities of practice. Medical Teacher, (32), 425-428. https://doi.org/10.3109/01421591003677897

Swanwick, T. (2008). See one, do one, then what? Faculty development in postgraduate medical education. Postgraduate Medical Journal, 84(993), 339-343. https://doi.org/10.1136/pgmj.2008.068288

Tiwari, R.R., Sharma. K., \& Zodpey, S.P. ( 2012). Situational analysis of nursing education and work force in India. Nursing Outlook, 61, 129-136. https://doi.org/10.1016/j.outlook.2012.07.012

Tsen, L.C., Borus, J.F., Nadelson, C.C., Seely, E.W., Haas, A., \& Fuhlbrigge, A.L. (2012). The Development, Implementation, and Assessment of an Innovative Faculty Mentoring Leadership Program. Academic Medicine, 87(12), 1757-1761. https://doi.org/10.1097/ACM.0b013e3182712cff

Upvall, M.J., Leffers, J.M., \& Mitchell, E.M. (2014). Introduction and Perspectives of Global Health. In Upvall, M.J \& Leffers, J.M. (Eds.), Global Health Nursing: Building and Sustaining Partnerships. New York: Springer Publisher.

Virk, M.L. (1998). Handbook of the Universities of Pakistan. UGC, Islamabad.

Watkins, R., Meiers, M.W, \& Visser, Y.L. (2012). A Guide to Assessing Needs. Washington D.C: World Bank. https://doi.org/10.1596/978-0-8213-8868-6

Whitcomb, M.E. (2003). The medical school's faculty is its most important asset. Academic Medicine, 78(2), 117-118. https://doi.org/10.1097/00001888-200302000-00001

Zamanzadeh, V., Valizadeh, L., Nedarandeh, R., Monadi, M, \& Azadi, A. (2013). Factors influencing the men entering the nursing profession, \& understanding the challenges faced by them: Iranian and developed countries perspectives. Nurse Midwifery Studies, 2(4), 49-56. https://doi.org/10.5812/nms.12583

\section{Copyrights}

Copyright for this article is retained by the author(s), with first publication rights granted to the journal.

This is an open-access article distributed under the terms and conditions of the Creative Commons Attribution license (http://creativecommons.org/licenses/by/4.0/). 